\title{
Characterization of chitin deacetylase genes in the Diaphorina citri genome
}

Sherry Miller ${ }^{1,2}$, Teresa D. Shippy ${ }^{1}$, Blessy Tamayo ${ }^{3}$, Prashant S Hosmani ${ }^{4}$, Mirella Flores-

Gonzalez $^{4}$, Lukas A Mueller ${ }^{4}$, Wayne B Hunter ${ }^{5}$, Susan J Brown ${ }^{1}$, Tom D'elia ${ }^{3}$ and Surya Saha ${ }^{4,6^{*}}$

${ }^{1}$ Division of Biology, Kansas State University, Manhattan, KS 66506

${ }^{2}$ Allen County Community College, Burlingame, KS 66413

${ }^{3}$ Indian River State College, Fort Pierce, FL 34981

${ }^{4}$ Boyce Thompson Institute, Ithaca, NY 14853

${ }^{5}$ USDA-ARS, U.S. Horticultural Research Laboratory, Fort Pierce, FL 34945

${ }^{6}$ Animal and Comparative Biomedical Sciences, University of Arizona, Tucson, AZ 85721

*Corresponding Author

\begin{abstract}
Chitin deacetylases (CDAs) are one of the least understood components of insect chitin metabolism. The partial deacetylation of chitin polymers appears to be important for the proper formation of higher order chitin structures, such as long fibers and bundles, that contribute to the integrity of the insect exoskeleton and other structures. Some CDAs may also play a role in bacterial defense. Here we report the characterization of four CDA genes from the Asian citrus psyllid, Diaphorina citri, laying the groundwork for future study of these genes. D. citri is the vector for Candidatus Liberibacter asiaticus (CLas), which is responsible for the global
\end{abstract}


outbreak of Huanglongbing (citrus greening) disease. The manual annotation was done as part of a collaborative community annotation project (https://citrusgreening.org/annotation/index).

\section{Introduction}

Chitin deacetylases (CDAs) are metalloenzymes that partially deacetylate chitin polymers [1]. CDA activity in insects was first reported in the cabbage looper Trichoplusia ni [2]. In Drosophila melanogaster, several CDAs were found to play a role in tracheal development $[3,4]$. More recently, Genomic and phylogenetic studies have shown that CDAs are present widely in insects and can be classified into five different groups $[5,6]$. Most holometabolous insects have at least one representative of each of the five CDA groups, while the hemimetabolous insects that have been examined lack group II and group V genes [7]. The exact role of insect CDAs is not well understood, but they may play a role in organization of chitin molecules into higher order structures [8]. Loss of function experiments indicate that some CDAs play an essential role in growth and development, making them a potential target for insect pest control [6,9-12]. Here we describe the chitin deacetylase gene family in the Asian citrus psyllid, Diaphorina citri. D. citri is the vector for Candidatus Liberibacter asiaticus (CLas), which is responsible for the global outbreak of Huanglongbing (citrus greening) disease. We identified four chitin deacetylase genes in the $D$. citri v3 genome, three of which have multiple isoforms. As in other hemipterans, only groups I, III and IV are represented [6]. 


\section{Results}

Chitin deacetylase genes in the D. citri v3 genome [13] were identified and manually annotated.

These genes were classified into groups following the precedents established in other insects

$[5,6]$.

Group I chitin deacetylases

Most insects have two group I genes named CDA1 and CDA2 (Table 1). The proteins encoded by these genes have an $\mathrm{N}$-terminal chitin-binding domain (ChBD), a low-density lipoprotein receptor class A domain (LDLa), and a deacetylase catalytic domain [5]. RNAi of group I CDAs in a variety of insects suggests that loss of function of CDA1 or CDA2 can result in lethality and therefore these genes could be potential targets for pest control methods $[6,8-12,14]$. Recent experiments in Tribolium suggest that TCCDA1 and TCCDA2 are required for organization of chitin into longer fibers that are important for cuticular strength [8].

Estimated Number of Chitin Deacetylase Homologs

\begin{tabular}{|l|l|l|l|l|l|l|}
\hline & Group I & Group II & Group III & Group IV & Group V & Total \\
\hline D. melanogaster & $2^{*}$ & 1 & 1 & $1^{*}$ & 1 & 6 \\
\hline A. gambiae & $2^{*}$ & 1 & 1 & 1 & 0 & 5 \\
\hline T. castaneum & $2^{*}$ & 1 & 1 & $1^{*}$ & 4 & 9 \\
\hline B. mori & $2^{*}$ & 1 & 1 & 1 & 3 & 8 \\
\hline A. mellifera & $2^{*}$ & 1 & 1 & $1^{*}$ & 0 & 5 \\
\hline N. vitripennis & 2 & 1 & 1 & 1 & 0 & 5 \\
\hline R. prolixus & 2 & 0 & 1 & 1 & 0 & 4 \\
\hline A. pisum & 2 & 0 & 1 & 1 & 0 & 4 \\
\hline N. Iugens & 2 & 0 & 1 & 1 & 0 & 4 \\
\hline D. citri & $2^{*}$ & 0 & 1 & $1^{*}$ & 0 & 4 \\
\hline
\end{tabular}


Table 1. D. citri gene numbers were determined based on annotation of the $D$. citri genome v3.

All other ortholog numbers were obtained from published sources $[5,6,29-37]$. An asterisk $(*)$

indicates that isoforms have been found for at least one member of the group in that organism.

As expected, we identified two group I genes in $D$. citri, which we named $C D A 1$ and $C D A 2$. Both genes encode proteins with the typical group I domain structure (Figure 1). We identified two isoforms each for $D$. citri $C D A 1$ and $C D A 2$ (Table 2). CDA2 has previously been shown to have multiple isoforms in several holometabolous insect species, with the transcripts differing only in the use of one alternative exon $[5,11,14]$. This gene structure is conserved in D. citri CDA2 with alternate exons $3 a$ and $3 b$. The two $D$. citri CDA1 isoforms differ in the presence or absence of a $24 \mathrm{bp}$ exon upstream of the last exon. Expression data from RNA-Seq datasets available through the Citrusgreening Expression Network (CGEN) [15] suggest that, in general, expression of CDA1 and CDA2 is higher in nymphs and eggs than in adults (Fig. 2A).

Chitin Deacetylase Genes in D. citri

\begin{tabular}{|c|l|c|c|c|c|c|c|}
\hline Gene/Isoform & OGSv3 ID & \multicolumn{2}{|c|}{ Gene model } & \multicolumn{3}{c|}{ Evidence supporting annotation } \\
\hline & & Complete & Partial & MCOT & IsoSeq & RNASeq & Ortholog \\
\hline $\begin{array}{c}\text { CDA1 } \\
\text { (Group I) }\end{array}$ & $\begin{array}{c}\text { Dcitr04g03590.1.1 } \\
\text { Dcitr04g03590.1.2 }\end{array}$ & $X$ & & $X$ & $X$ & $X$ & $X$ \\
\hline $\begin{array}{c}\text { CDA2 } \\
\text { (Group I) }\end{array}$ & Dcitr04g03540.1.1 & $\mathrm{X}$ & & & $\mathrm{X}$ & $\mathrm{X}$ & $\mathrm{X}$ \\
\hline $\begin{array}{c}\text { CDA3 } \\
\text { (Group III) }\end{array}$ & Dcitr02g03950.1.1 & $\mathrm{X}$ & & $\mathrm{X}$ & $\mathrm{X}$ & & $\mathrm{X}$ \\
\hline
\end{tabular}




\begin{tabular}{|c|l|l|l|l|l|l|l|}
\hline CDA5 & Dcitr01g12310.1.1 & & $X$ & $X$ & $X$ & $X$ & $X$ \\
(Group IV) & Dcitr01g12310.1.2 & & & & & & \\
& Dcitr01g12310.1.3 & & & & & & \\
& Dcitr01g12310.1.4 & & & & & & \\
\hline & Dcitr01g12310.1.5 & & & & & & \\
\hline
\end{tabular}

Table 2. Each manually annotated gene has been assigned an OGSv3.0 gene identifier. Each

gene has been termed partial or complete based on available evidence. Evidence types used for manual annotation of each gene are also indicated. More information on these evidence sources is available in [22].

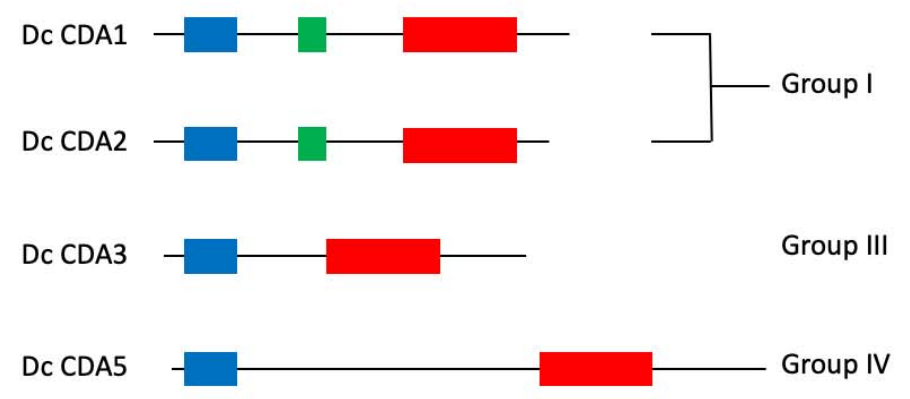

\begin{tabular}{|l|}
\hline \\
Deacetylase Catalytic Domain \\
Chitin Binding Domain \\
Low-Density Lipoprotein Receptor Class A Domain \\
Linker Region
\end{tabular}

Figure 1. Chitin Deacetylase Domain Organization in D. citri. Chitin deacetylases are categorized by group based on phylogenetic analysis, sequence similarity, and domain organization. $D$. citri domain analysis was performed using InterPro [28]. CDA5 is represented by the protein encoded by the de novo-assembled transcript MCOT06229.1.CO [17] because a small portion of the CDA5 gene is missing from the genome. 
In Drosophila and Tribolium, the CDA1 and CDA2 orthologs are adjacent to one another in the genome $[3,5]$ on chromosome 3 and 5 , respectively. The conserved clustering of these genes suggests there may be evolutionary constraint on their physical location. We found that the $D$. citri $C D A 1$ and $C D A 2$ orthologs are also adjacent to one another on chromosome 4 . In the $D$. citri $\mathrm{v}$ genome these genes are separated by approximately $50 \mathrm{~kb}$, although this distance appears to be inflated by falsely duplicated fragments of both genes in this assembly.

Group III chitin deacetylases

We identified one group III CDA in the D. citri v3 genome (Table 1). This gene has been previously described and was named CDA3 because of its orthology to Nilaparvata lugens CDA3 [16]. Like group III CDAs in other insects, D. citri CDA3 contains a ChBD and catalytic domain but lacks the LDLa domain found in group I CDAs (Figure 1). Due to improvements in the genome assembly, our curated CDA3 model from genome v3 has additional 3' sequence compared to the previously reported model, which was based on genome v1.1 $[16,17]$. The resulting predicted protein is almost 50 amino acids longer, with additional conserved sequence at the Cterminus.

Yu et al. [16] reported that RNAi knockdown of CDA3 had no effect on molting or wing development. Instead, their results implicated $C D A 3$ in the $D$. citri bacterial immune response. Recombinant CDA3 showed antibacterial activity against gram-positive bacteria, but had no effect on gram-negative bacteria. Moreover, injection of either Escherichia coli (gram-negative) or Staphylococcus aureus (gram-positive) bacteria into D. citri increased CDA3 expression in the midgut and decreased its expression in the fat body, although the timeline of these effects is 
bioRxiv preprint doi: https://doi.org/10.1101/2020.12.22.424074 - this version posted December 22, 2020. The copyright holder for this preprint (which was not certified by peer review) is the author/funder, who has granted bioRxiv a license to display the preprint in perpetuity. It is made available under aCC-BY-NC 4.0 International license.

not certain. To determine whether infection by CLas, a gram-negative bacterium, might also affect CDA3 expression, we used CGEN [15] to compare expression of D. citri CDA3 in RNA-Seq datasets from CLas+ and CLas- guts [18], midguts [19] and whole bodies ([20] and NCBI BioProject PRJNA609978).

A

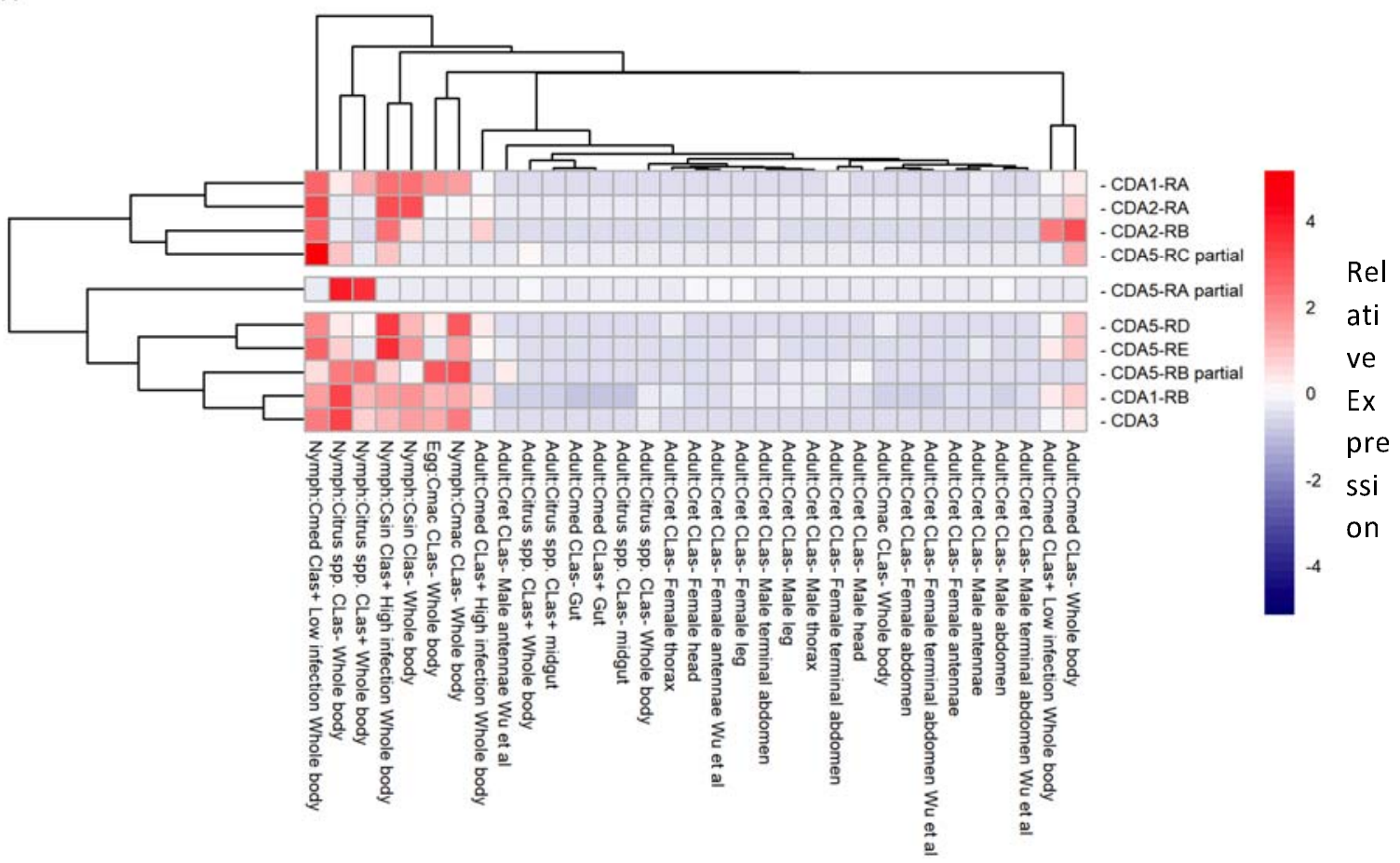




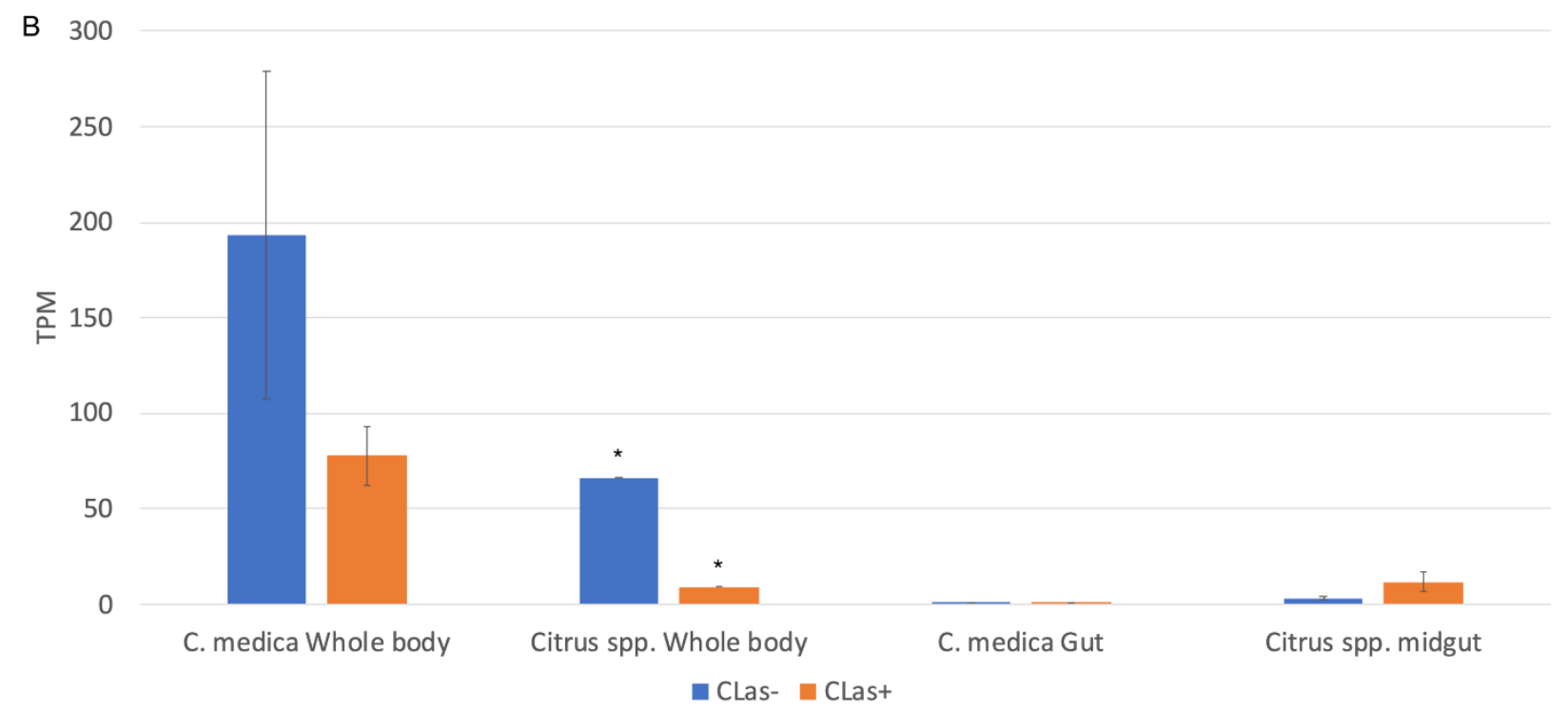

Figure 2. (A) Heatmap displaying relative expression levels of all annotated chitin deacetylase genes in RNA-Seq datasets from various life stages, tissues and CLas infection states. (B) Expression levels (TPM) of CDA3 (Dcitr02g03950.1.1) in tissues from CLas+ and CLas- psyllids fed on two different types of citrus plants. Standard error bars are shown for all expression values except those marked with an asterisk $\left({ }^{*}\right)$, which had only one replicate. Expression levels were obtained from the Citrusgreening Expression Network [15].

CDA3 expression in was lower in CLas + versus CLas- whole body tissue in data from two different RNA-Seq experiments (Figure 2B). Expression of CDA3 in midgut and gut tissues was very low in all samples but there was a slight increase in CLas+ versus CLas- midgut expression (Figure 2B). While the significance of these expression differences is not clear, they may warrant further investigation.

Group IV chitin deacetylases

Most insects examined to date have one group IV CDA, typically called CDA5 (CDA4 in N. lugens)

(Table 1). CDA5 has been shown to have multiple isoforms in Tribolium and Drosophila [5]. 
bioRxiv preprint doi: https://doi.org/10.1101/2020.12.22.424074; this version posted December 22, 2020. The copyright holder for this preprint (which was not certified by peer review) is the author/funder, who has granted bioRxiv a license to display the preprint in perpetuity. It is made available under aCC-BY-NC 4.0 International license.

Consistent with these observations, we identified and annotated five different isoforms of CDA5 in D. citri (Table 2). Unfortunately, the annotated models are missing a small amount of 3' sequence due to genome assembly issues. However, we identified a de-novo assembled transcript (MCOT06229.1.CO) that appears to encode the full-length protein (Figure 1). The missing genome sequence does not affect the conserved function domains of CDA5. Four of the five transcript isoforms encode proteins containing both an N-terminal ChBD and a C-terminal catalytic domain, as seen in other insect CDA5 orthologs. The remaining isoform (CDA5-RB) differs at the $5^{\prime}$ end and apparently lacks a ChBD-encoding region.

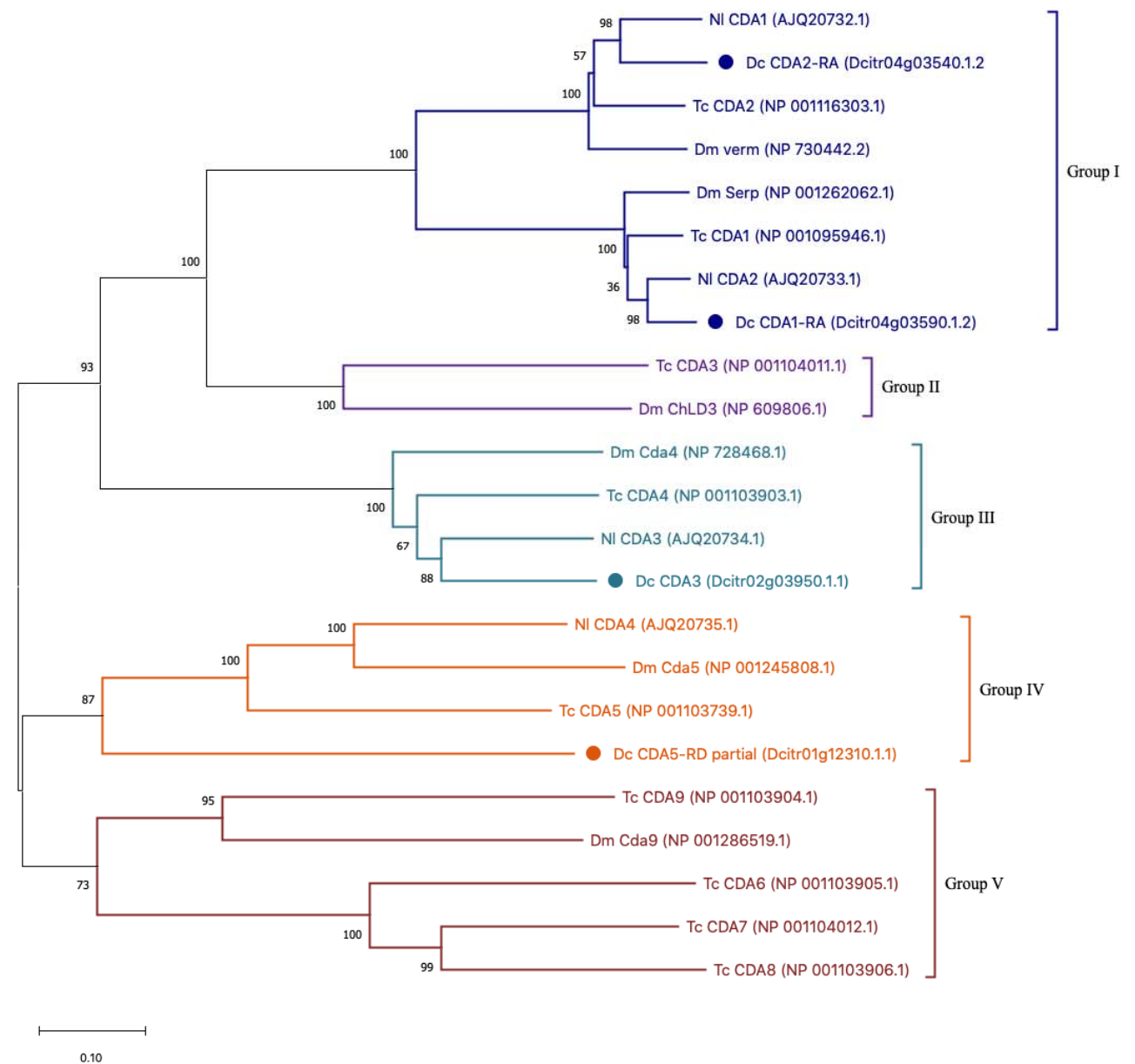


Figure 3. Phylogenetic tree of chitin deacetylase family members. ClustalW was used to perform the multiple sequence alignment. The tree was constructed with MEGAX software using neighbor-joining analysis with 100 bootstrap replications. Drosophila melanogaster (Dm), Tribolium castnaeum (Tc), Nilaparvata lugens (NI), and Diaphorina citri (Dc). D. citri protein branches are marked with a circle. Colors delineate established chitin deacetylase groups.

Other chitin deacetylase groups

We did not find any group II or group V CDAs in the D. citri v3 genome (Figure 3). To our knowledge CDAs from these groups have not been found in any hemipteran insects examined to date [6], so their absence in D. citri was expected.

\section{Conclusion}

Chitin is a polysaccharide found primarily in invertebrates, where it is required for the exoskeleton and other structures. Chitin deacetylases modify these molecules and are believed to play a role in the assembly of higher order chitin structures, although their precise role in insects is not well characterized. At least some of the members of this gene family seem to be required for normal development in many insects. The essentiality and limited phylogenetic distribution of these genes makes them attractive targets for pest control via gene knockdown methods such as RNAi. As part of a community project to annotate the genome of $D$. citri, the vector of Huanglongbing (citrus greening disease), we identified and annotated four chitin deacetylase genes in the $D$. citri v3 genome. Three of these genes have multiple transcriptional isoforms, so having correctly annotated transcripts will be particularly valuable for any future experiments targeting these genes. 


\section{Materials and Methods}

Chitin deacetylase genes in D. citri genome v3 [13] were identified by BLAST search of $D$. citri sequences with chitin deacetylase orthologs from other insects. Orthology was confirmed by reciprocal BLAST of the NCBI non-redundant protein database. Genes were manually annotated in Apollo 2.1.0 [21] using available evidence, including RNA-Seq reads, IsoSeq transcripts and de novo-assembled transcripts. A more detailed annotation protocol is available at protocols.io [22]. Multiple alignments were performed using MUSCLE [23] and phylogenetic trees were constructed in MEGA7 [24] or MEGA X [25]. Table 3 contains a list of orthologs used in the phylogenetic analysis. Expression data from CGEN [18] was visualized using the pheatmap package of $\mathrm{R}[26,27]$ or Microscoft Excel.

Orthologs Used in Phylogenetic Analysis

\begin{tabular}{|l|l|l|l|}
\hline Species & Accession & Name in NCBI & Name in Tree \\
\hline Nilaparvata lugens & AJQ20732.1 & chitin deacetylase 1 & NI CDA1 \\
\hline Nilaparvata lugens & AJQ20733.1 & chitin deacetylase 2 & NI CDA2 \\
\hline Nilaparvata lugens & AJQ20734.1 & chitin deacetylase 3 & NI CDA3 \\
\hline Nilaparvata lugens & AJQ20735.1 & chitin deacetylase 4 & NI CDA4 \\
\hline Tribolium castaneum & NP_001095946.1 & $\begin{array}{l}\text { chitin deacetylase 1 } \\
\text { precursor }\end{array}$ & Tc CDA1 \\
\hline Tribolium castaneum & NP_001116303.1 & $\begin{array}{l}\text { chitin deacetylase 2 } \\
\text { isoform B precursor }\end{array}$ & Tc CDA2 \\
\hline Tribolium castaneum & NP_001104011.1 & $\begin{array}{l}\text { chitin deacetylase 3 } \\
\text { precursor }\end{array}$ & Tc CDA3 \\
\hline Tribolium castaneum & NP_001103903.1 & $\begin{array}{l}\text { chitin deacetylase 4 } \\
\text { precursor }\end{array}$ & Tc CDA4 \\
\hline Tribolium castaneum & NP_001103739.1 & $\begin{array}{l}\text { chitin deacetylase 5 } \\
\text { isoform A precursor }\end{array}$ & Tc CDA5 \\
\hline Tribolium castaneum & NP_001103905.1 & $\begin{array}{l}\text { chitin deacetylase 6 } \\
\text { precursor }\end{array}$ & Tc CDA6 \\
\hline
\end{tabular}


bioRxiv preprint doi: https://doi.org/10.1101/2020.12.22.424074; this version posted December 22, 2020. The copyright holder for this preprint (which was not certified by peer review) is the author/funder, who has granted bioRxiv a license to display the preprint in perpetuity. It is made available under aCC-BY-NC 4.0 International license.

\begin{tabular}{|l|l|l|l|}
\hline Tribolium castaneum & NP_001104012.1 & $\begin{array}{l}\text { chitin deacetylase 7 } \\
\text { precursor }\end{array}$ & Tc CDA7 \\
\hline Tribolium castaneum & NP_001103906.1 & $\begin{array}{l}\text { chitin deacetylase 8 } \\
\text { precursor }\end{array}$ & Tc CDA8 \\
\hline Tribolium castaneum & NP_001103904.1 & $\begin{array}{l}\text { chitin deacetylase 9 } \\
\text { precursor }\end{array}$ & Tc CDA9 \\
\hline Drosophila melanogaster & NP_001262062.1 & serpentine, isoform C & Dm Serp \\
\hline Drosophila melanogaster & NP_730442.2 & vermiform, isoform G & Dm verm \\
\hline Drosophila melanogaster & NP_609806.1 & ChLD3 & Dm ChLD3 \\
\hline Drosophila melanogaster & NP_728468.1 & chitin deacetylase-like 4 & Dm Cda4 \\
\hline Drosophila melanogaster & NP_001245808.1 & $\begin{array}{l}\text { chitin deacetylase-like 5, } \\
\text { isoform I }\end{array}$ & Dm Cda5 \\
\hline Drosophila melanogaster & NP_001286519.1 & $\begin{array}{l}\text { chitin deacetylase-like 9, } \\
\text { isoform B }\end{array}$ & Dm Cda9 \\
\hline
\end{tabular}

Table 3. Species, accession number, full name and abbreviated name are provided for all orthologs used in phylogenetic analysis.

\section{Acknowledgements}

We thank Dr. Josh Benoit for assistance with data visualization. This research was funded by USDA-NIFA grant 2015- 70016-23028 and an Institutional Development Award (IDeA) from the National Institute of General Medical Sciences of the National Institutes of Health under grant number P20GM103418.

\section{Author Contributions}

\begin{tabular}{|l|l|}
\hline Conceptualization & W.B.H., S.JB., T.D., L.M. \\
\hline Supervision & T.D.S, S.J.B., T.D, S.S \\
\hline Project Administration & S.J.B., T.D, S.S, L.M \\
\hline Investigation & S.M., T.D.S., B.T. \\
\hline Software & P.H., M.F-G, S.S. \\
\hline
\end{tabular}




\begin{tabular}{|l|l|}
\hline Methodology & P.H., M.F-G, S.S., T.D.S \\
\hline Funding Acquisition & S.J.B., T.D., W.B.H., L.M. \\
\hline Writing - Original Draft Preparation & S.M., T.D.S \\
\hline Writing - Review and Editing & S.J.B., S.S. \\
\hline
\end{tabular}

\section{References}

1. Kaczmarek MB, Struszczyk-Swita K, Li X, Szczęsna-Antczak M, Daroch M. Enzymatic modifications of chitin, chitosan, and chitooligosaccharides. Front. Bioeng. Biotechnol. $2019 ; 7: 243$

2. Guo W, Li G, Pang Y, Wang P. A novel chitin-binding protein identified from the peritrophic membrane of the cabbage looper, Trichoplusia ni. Insect Biochem Mol Biol. 2005;35:1224-34.

3. Luschnig S, Bätz T, Armbruster K, Krasnow MA. serpentine and vermiform encode matrix proteins with chitin binding and deacetylation domains that limit tracheal tube length in Drosophila. Curr Biol. 2006;16:186-94.

4. Wang S, Jayaram SA, Hemphälä J, Senti K-A, Tsarouhas V, Jin H, et al. Septate-junctiondependent luminal deposition of chitin deacetylases restricts tube elongation in the Drosophila trachea. Curr Biol. 2006;16:180-5.

5. Dixit R, Arakane Y, Specht CA, Richard C, Kramer KJ, Beeman RW, et al. Domain organization and phylogenetic analysis of proteins from the chitin deacetylase gene family of Tribolium castaneum and three other species of insects. Insect Biochem Mol Biol. 2008;38:440-51.

6. Xi Y, Pan PL, Ye YX, Yu B, Zhang CX. Chitin deacetylase family genes in the brown planthopper, Nilaparvata lugens (Hemiptera: Delphacidae). Insect Mol Biol. 2014;23:695-705. 
7. Zhu KY, Merzendorfer H, Zhang W, Zhang J, Muthukrishnan S. Biosynthesis, Turnover, and Functions of Chitin in Insects. Annu Rev Entomol. 2016;61:177-96.

8. Noh MY, Muthukrishnan S, Kramer KJ, Arakane Y. Group I chitin deacetylases are essential for higher order organization of chitin fibers in beetle cuticle. J Biol Chem. 2018;293:6985-95.

9. Liu X, Cooper AMW, Yu Z, Silver K, Zhang J, Zhu KY. Progress and prospects of arthropod chitin pathways and structures as targets for pest management. Pestic. Biochem. Physiol. 2019. p. 33-46.

10. Quan G, Ladd T, Duan J, Wen F, Doucet D, Cusson M, et al. Characterization of a spruce budworm chitin deacetylase gene: Stage- and tissue-specific expression, and inhibition using RNA interference. Insect Biochem Mol Biol. 2013;43:683-91.

11. Yan X, Zhao D, Zhang Y, Guo W, Wang W, Zhao K, et al. Identification and characterization of chitin deacetylase2 from the American white moth, Hyphantria cunea (Drury). Gene. 2018;670:98-105.

12. Yang W-J, Xu K-K, Yan X, Chen C-X, Cao Y, Meng Y-L, et al. Functional characterization of chitin deacetylase 1 gene disrupting larval-pupal transition in the drugstore beetle using RNA interference. Comp Biochem Physiol B Biochem Mol Biol. 2018;219-220:10-6.

13. Hosmani P, Flores-Gonzalez M, Shippy T, Vosburg C, Massimino C, Tank W, et al. Chromosomal length reference assembly for Diaphorina citri using single-molecule sequencing and $\mathrm{Hi}-\mathrm{C}$ proximity ligation with manually curated genes in developmental, structural and immune pathways. bioRxiv. 2019;869685; doi:10.1101/869685 
14. Wu J-J, Chen Z-C, Wang Y-W, Fu K-Y, Guo W-C, Li G-Q. Silencing chitin deacetylase 2 impairs larval-pupal and pupal-adult molts in Leptinotarsa decemlineata. Insect Mol Biol. 2019;28:5264.

15. Flores-Gonzalez M, Hosmani P, Fernandez-Pozo N, Mann M, Humann J, Main D, et al. Citrusgreening.org: An open access and integrated systems biology portal for the Huanglongbing (HLB) disease complex. bioRxiv. 2019;868364 doi:10.1101/868364

16. Yu HZ, Li NY, Li B, Toufeeq S, Xie YX, Huang YL, et al. Immune functional analysis of Chitin Deacetylase 3 from the Asian Citrus Psyllid Diaphorina citri. Int J Mol Sci. 2020;21.

17. Saha S, Hosmani PS, Villalobos-Ayala K, Miller S, Shippy T, Flores M, et al. Improved annotation of the insect vector of citrus greening disease: biocuration by a diverse genomics community. Database. 2017; doi: 10.1093/database/bax032

18. Kruse A, Fattah-Hosseini S, Saha S, Johnson R, Warwick E, Sturgeon K, et al. Combining 'omics and microscopy to visualize interactions between the Asian citrus psyllid vector and the Huanglongbing pathogen Candidatus Liberibacter asiaticus in the insect gut. PLoS One. 2017;12:e0179531.

19. Yu HZ, Li NY, Zeng XD, Song JC, Yu XD, Su HN, et al. Transcriptome analyses of Diaphorina citri midgut responses to Candidatus liberibacter asiaticus infection. Insects. 2020;11.

20. Vyas M, Fisher TW, He R, Nelson W, Yin G, Cicero JM, et al. Asian citrus psyllid expression profiles suggest candidatus liberibacter asiaticus-mediated alteration of adult nutrition and metabolism, and of nymphal development and immunity. PLoS One. 2015;10. 
21. Dunn NA, Unni DR, Diesh C, Munoz-Torres M, Harris NL, Yao E, et al. Apollo: Democratizing genome annotation. Darling AE, editor. PLOS Comput Biol. 2019;15:e1006790.

22. Shippy, TD; Miller, S; Massimino, C; Vosburg, C; Hosmani, PS; Flores-Gonzalez, M; Mueller, LA; Hunter, WB; Benoit, JB; Brown, SJ; D’elia, T; Saha S. Annotating genes in Diaphorina citri genome version 3. protocols.io. 2020; doi: 10.17504/protocols.io.bniimcce

23. MUSCLE. [accessed 2020 Oct 26]. https://www.ebi.ac.uk/Tools/msa/muscle/

24. Kumar S, Stecher G, Tamura K. MEGA7: Molecular Evolutionary Genetics Analysis Version 7.0 for Bigger Datasets. Mol Biol Evol. 2016;33:1870-4.

25. Kumar S, Stecher G, Li M, Knyaz C, Tamura K. MEGA X: Molecular evolutionary genetics analysis across computing platforms. Mol Biol Evol. Oxford University Press; 2018;35:1547-9.

26. R Core Team. R: A language and environment for statistical computing. R Foundation for Statistical Computing, Vienna, Austria. 2020. URL https://www.R-project.org/. Accessed Dec 172020.

27. Kolde R. pheatmap: Pretty Heatmaps. R package version 1.0.12. 2020.

28. InterPro. [accessed 2020 Nov 4]. https://www.ebi.ac.uk/interpro/

29. Adams MD, Celniker SE, Holt RA, Evans CA, Gocayne JD, Amanatides PG, et al. The genome sequence of Drosophila melanogaster. Science. 2000;2185-95.

30. Holt RA, Mani Subramanian G, Halpern A, Sutton GG, Charlab R, Nusskern DR, et al. The genome sequence of the malaria mosquito Anopheles gambiae. Science. 2002;298:129-49. 
31. Tribolium Genome Sequencing Consortium, Richards S, Gibbs RA, Weinstock GM, Brown SJ,

Denell R, et al. The genome of the model beetle and pest Tribolium castaneum. Nature.

2008;452:949-55.

32. Kawamoto M, Jouraku A, Toyoda A, Yokoi K, Minakuchi Y, Katsuma S, et al. High-quality genome assembly of the silkworm, Bombyx mori. Insect Biochem Mol Biol. 2019;107:53-62.

33. Elsik CG, Worley KC, Bennett AK, Beye M, Camara F, Childers CP, et al. Finding the missing honey bee genes: lessons learned from a genome upgrade. BMC Genomics. 2014;

doi:10.1186/1471-2164-15-86.

34. Werren JH, Richards S, Desjardins CA, Niehuis O, Gadau J, Colbourne JK, et al. Functional and evolutionary insights from the genomes of three parasitoid Nasonia species. Science. 2010; doi:10.1126/science.1178028.

35. Mesquita RD, Vionette-Amaral RJ, Lowenberger $C$, Rivera-Pomar R, Monteiro FA, Minx $P$, et al. Genome of Rhodnius prolixus, an insect vector of Chagas disease, reveals unique adaptations to hematophagy and parasite infection. Proc Natl Acad Sci U S A. 2015;112:14936-41.

36. International Aphid Genomics Consortium. Genome sequence of the pea aphid Acyrthosiphon pisum. PLoS Biol. 2010; doi:10.1371/journal.pbio.1000313

37. Ma W, Xu L, Hua H, Chen M, Guo M, He K, et al. Chromosomal-level genomes of three rice planthoppers provide new insights into sex chromosome evolution. Mol Ecol Resour. 2020; doi: 10.1111/1755-0998.13242. 